\title{
HEALTH RISK OF DENTAL UNIT WATERLINE SYSTEM TO DENTAL PATIENTS - AN ISSUE OF CONCERN
}

C.S. Chua, A.R. Fathilah, W.H. Himratul-Aznita. Health Risk of Dental Unit Waterline System to Dental Patients - An Issue of Concern. Annal Dent Univ Malaya 2013; 20(1): $20-26$

\begin{abstract}
Water delivered through dental unit waterline system (DUWS) is often reported contaminated with microbes dislodged from biofilm that forms within the tubing of a dental chair unit (DCU). ADM: The study aimed at evaluating the sanitary level of DCU water from a teaching dental clinic. Materials: The presence of pathogenic bacteria which include total coliforms, faecal coliforms, E. coli, faecal streptococci and P. aeruginosa were determined using conventional microbiological methods while PCR technique was used to identify other microbial contaminants. Result: $\mathrm{pH}$ of DCU water was found slightly acidic at $\mathrm{pH}$ 5.4-5.5 and the temperature was $23^{\circ} \mathrm{C}$. Pathogenic contaminants were absent but the DCU water was highly loaded with Sphingomonas rhizogenes (17.9\%), Sphingomonas dokdonesis (79.5\%), Sphingomonas mucosissima (1.1\%) and Methylobacterium radiotolerans (1.5\%). The high load of microbes that exceeded $200 \mathrm{cfu} / \mathrm{ml}$ was of great concern as it failed to meet recommendation set by the American Dental Association.
\end{abstract}

\section{Keywords}

Biofilm, Dental chair unit, Infection control, Microbial load.

\section{INTRODUCTION}

Output water delivered through Dental Unit Waterline System (DUWS) is often highly contaminated with microorganisms $(1,2)$. It has been reported that these microbes are dislodged from biofilm that tends to form within the multiple tubing of a dental chair unit. Although bacteria recovered from DUWS are mainly harmless Gram-negative aerobes, their high presence in dental chair unit (DCU) water are of concern as it contradicts the general infection control practice requirement. The presence of high microbial contaminants has been associated with the high concentration of endotoxin in DUWS water (3). Vigorous cleaning procedures of the DUWS are regularly performed to ensure good quality
Original Article

C.S. Chua, A.R. Fathilah, W.H. Himratul-Aznita
Department of Oral Biology and Biomedical
Sciences
Faculty of Dentistry
University of Malaya
50603 Kuala Lumpur
Malaysia
Corresponding Author:
Dr. Fathilah Abdul Razak
Email: fathilah@um.edu.my

water is delivered to dental patients and these include the use of anti-retraction valves (4), flushing (5), filtration, independent clean water system, chemical treatments $(6,7)$, cleaning and disinfection system (8), as well as the use of modified tubing material for DCU (9). However, despite the various measures taken to ensure clean water supply to DCUs, microbial contamination of DUWS is still being reported. This study was carried out to investigate the microbiological quality of water delivered in the DUWS of a teaching clinic in a local dental school.

\section{MATERIALS AND METHODS}

Water samples from 13 DCUs were obtained from a dental teaching clinic in a local university. This model employed clean water supplied by an independent reservoir filled with distilled water. In other words, water used in these DCUs had bypassed main connections to the municipal water supply.

\section{COLLECTION OF WATER SAMPLES}

Thirteen collections were made over a period of two months with a total of 572 water samples. Sampling was carried out in the early morning (around $8.30 \mathrm{am}$ ) after a nightly disuse of the DCU. In each sampling, water samples were collected from both the output and input water of the DCU. The former consisted of water from the air-water syringe (AWS), low speed hand piece (LSH) and high speed hand piece (HSH) while the later consisted of distilled water (DW) in the reservoir of each DCU. 
Before the start of each collection, the points of each of the water sources were carefully wiped with alcohol to ensure sterility of their surfaces. Water was then allowed to run to waste for about one minute before it was aseptically collected into sterile universal and polypropylene bottles for laboratory analyses. The temperature and $\mathrm{pH}$ of the water samples were recorded using a portable temperature$\mathrm{pH}$ meter (Thermoline) before they were transported on ice to the laboratory for microbial analyses.

\section{MICROBIOLOGICAL ANALYSES}

To each of the water samples, microbiological analyses that included heterotrophic plate count, total coliforms count, faecal coliforms count, Escherichia coli count, faecal streptococci count and Pseudomonas aeruginosa count were carried out following the techniques proposed in the Standard Methods for Examination of Water and Wastewater (10).

\section{a) Heterotrophic plate count}

$0.1 \mathrm{~mL}$ of water sample was evenly spread on to R2A agar plate (Difco) and incubated at $28^{\circ} \mathrm{C}$ for 7 days. Following incubation the mean colony forming units (cfu) of triplicate and the abundance percentage of different types of colonies were calculated. Dilutions of the water samples were made using phosphate buffered solutions if the cfu counts on the plate did not fall within the range of 30-300 colonies.

\section{b) Total coliforms count}

$100 \mathrm{~mL}$ of water sample was run through a $0.45 \mu \mathrm{m}$ membrane filter (Whatman). The membrane filter was removed and placed on to $m$ Endo agar LES plate (Difco). Following incubation at $35.0 \pm 0.5^{\circ} \mathrm{C}$ for $22-24$ hours, the number of pink to dark-red colour colonies displaying a metallic surface sheen that formed on the plate was recorded as the number of coliforms present in the sample. The formation of doubtful colonies was verified by transferring the colonies into lauryl tryptose solutions (Difco) and brilliant green lactose broth (Difco). Following incubation at $35.0 \pm 0.5{ }^{\circ} \mathrm{C}$ for 48 hours, the production of a gas would confirm them as coliforms.

\section{c) Faecal coliforms count}

$100 \mathrm{~mL}$ of water sample was run through a $0.45 \mu \mathrm{m}$ membrane filter (Whatman). The membrane filter was removed and placed on to $\mathrm{m}$ FC agar plate (Difco) which has been supplemented with rosolic acid (1\%). Following incubation at $44.5 \pm 0.2{ }^{\circ} \mathrm{C}$ for $22-24$ hours, the number of blue colonies formed was recorded as the number of faecal coliforms in the sample. Doubtful colonies were verified following the same procedure as mentioned for the total coliform. d) Escherichia coli count

Membrane filters from water samples showing positive total coliform was removed and placed on to a nutrient agar plate containing 4-methylumbelliferyl- $\beta$-Dglucuronide (NA-MUG) (Difco). Following incubation at $35.0 \pm 0.5^{\circ} \mathrm{C}$ for 4 hours, the number of cfu that produces fluorescence under UV illumination was recorded as the number of E. coli present in the sample.

\section{e) Faecal streptococci count}

$100 \mathrm{~mL}$ of water sample was filtered through a $0.45 \mu \mathrm{m}$ membrane filter (Whatman). The membrane filter was removed and then placed on to $\mathrm{m}$ Enterococcus agar plate (Difco). Following incubation at $35.0 \pm 0.5{ }^{\circ} \mathrm{C}$ for 48 hours, the number of cfu was recorded as the number of faecal streptococci in the water sample.

\section{f) Pseudomonas aeruginosa count}

$500 \mathrm{~mL}$ of water sample was filtered through a $0.45 \mu \mathrm{m}$ membrane filter (Whatman). The membrane filter was removed and placed on to M-PA-C agar plate (BBL). Following incubation at $41.5 \pm 0.5^{\circ} \mathrm{C}$ for 72 hours, the cfu was recorded as the number of $\mathrm{P}$. aeruginosa present in the water sample.

Statistical analyses were carried out using Statistical Package for the Social Sciences (SPSS) version 12.0.1. Bacterial loads in different water sources (air-water syringe, low and high speed hand pieces and distilled water) were compared to the standard recommended by the ADA $(\leq 200 \mathrm{cfu} / \mathrm{mL})$ using one sample t-tests on a log-transformed heterotrophic plate count. Paired t tests were also carried out to compare bacterial load of the input water (distilled water) and output water (air-water syringe, low and high speed hand pieces). Statistical significance was assumed at a $\mathrm{P}$ value of $<0.05$.

\section{Bacterial identification}

Microorganisms isolated from water samples were subcultured on to R2A agar plates and incubated for 24 hours at $37{ }^{\circ} \mathrm{C}$. The colonies formed were harvested for use in bacterial identification using $16 \mathrm{~S}$ rDNA molecular approach. The genomic DNA of the isolated bacteria was extracted using the GeneJETTM Genomic DNA Purification Kit (Fermentas).

\section{a) Polymerase chain reaction (PCR)}

100 ng of purified genomic DNA was used as DNA template in the PCR. Primers 27F (5'-AGAGTTTGATC/TA/ CTGGCTCAG-3') and 1495R (5'-CGGC/TTACCTTGT TACGA C-3') were used to amplify a 1500-bp region of the 16S rDNA gene. The reaction mixtures contained PCR buffer $(2.0 \mathrm{mM} \mathrm{MgCl} 2 ; 200 \mu \mathrm{M}$ for each dATP, dCTP, dGTP and dGTP; $300 \mathrm{mM}$ for each forward and reverse primer; and $0.025 \mathrm{U}$ of Taq DNA polymerase (Fermentas). The reaction mixtures were incubated for an 
initial denaturation at $94^{\circ} \mathrm{C}$ for 2 minutes, followed by 35 cycles at $94{ }^{\circ} \mathrm{C}$ for 30 seconds, at $50{ }^{\circ} \mathrm{C}$ for 30 seconds, and at $72{ }^{\circ} \mathrm{C}$ for 2 minutes before a final extension at 72 ${ }^{\circ} \mathrm{C}$ for 10 minutes. The PCR products were then purified for further analysis using the GeneJETTM purification column (Fermentas).

b) $16 \mathrm{~S}$ rDNA gene sequencing and bacterial identification

The purified PCR products with A260/A280 ratio between 1.7 and 2.0 were sent to an external laboratory for DNA sequencing. The isolates were identified by comparing their 16S rDNA sequences to those in the GenBank nucleotide sequence databases using the Basic Local Alignment Search Tool (BLAST) family of computer programmes (http://blast.ncbi.nlm.nih.gov/Blast.cgi).

\section{RESULTS}

The mean temperature of the DCU's water was at 23.41 $\pm 0.86{ }^{\circ} \mathrm{C}$ and was slightly acidic at $\mathrm{pH} 5.46 \pm 0.17$. The mean for heterotrophic plate count of all water samples was determined at $3.88 \pm 0.28 \log 10 \mathrm{cfu} / \mathrm{mL}$ (3981$14454 \mathrm{cfu} / \mathrm{mL}$ ) (Figure 1), which significantly exceeded the acceptable standard level recommended by the ADA $(\mathrm{P}<0.001)$ (Table 1). Comparatively, the heterotrophic plate count from the air-water syringe was found to be significantly lower than that of the distilled water $(\mathrm{P}=$ 0.005). No significant difference was observed between the low speed and high speed hand pieces to that of the distilled water $(\mathrm{P}>0.05)$ (Table 2).

Microbial analysis of water samples from all 13 DCUs revealed the negative presence of total coliforms, faecal coliforms, E. coli, faecal streptococci and $\mathrm{P}$. aeruginosa. However, 4 different colonies were routinely isolated from the water samples. When compared to the GenBank nucleotide sequence database, these bacteria were identified as Gram-negative bacteria (Figure 2) belonging to the genus Sphingomonas (98.5\%) and
Methylobacterium (1.5\%). The abundance percentage of each individual bacterium was shown in Table 3.

\section{DISCUSSION}

DUWS refers to the narrow interconnected tubing network within a dental chair. The physics of laminar flow of water passing through DUWS and the long stagnation of water in the entire column facilitate the proliferation of microorganisms originating from the environment in the tubing. This often causes the water delivered to the patients' mouth to be heavily contaminated with microbes. The possibility of getting infected by an infectious disease during dental treatment has created awareness among the public. Despite the various approaches and guidelines (12) proposed to tackle issues on contamination of DUWS water, serious cases of water borne infections associated with water in a dental-care setting is still being reported (13) and thus, highlight the importance of maintaining a safe working environment for both dental personnel and patients.

In this study, the temperature of water from the DCUs was recorded around $23^{\circ} \mathrm{C}$ and the $\mathrm{pH}$ was about $\mathrm{pH}$ 5.4-5.5, which is slightly acidic when compared to the optimum $\mathrm{pH}$ of water for drinking purpose recommended by the World Health Organization at $\mathrm{pH}$ 6.5-9.5 (14). Located in a hot tropical country, the clinic is fully airconditioned throughout its operation hours during the day. In the evening and at any other times however, the conditioning system is switched off leaving the clinic in a warm environment. Under such condition, water that remains stagnant in the DCUs while not in used may have some influence on the quality of outgoing water from the chair. Although short exposures to the slightly acidic water during treatment may not pose significant health risk to patients, considering the tendency that some patients might swallow some water during treatment, the $\mathrm{pH}$ of this DCU water is thus, not potable and does not conform to a good general infection practice. However, considering accidental swallowing of water during dental treatment

Table 1. Comparison of heterotrophic plate count from different water sources to the standard recommended by the ADA $(200 \mathrm{cfu} / \mathrm{mL}=2.301 \log 10)$. Comparison was made using one sample $t$ test and the $\mathrm{P}$ values are as indicated in the table.

\begin{tabular}{lcccc}
\hline Water sources & \multicolumn{1}{c}{$\begin{array}{c}\text { Mean } \\
\text { (SD) }\end{array}$} & $\begin{array}{c}\text { Mean diff. } \\
\mathbf{( 9 5 \% ~ C l )}\end{array}$ & $\begin{array}{c}\text { t-statistic } \\
\text { (df) }\end{array}$ & $P$ value \\
\hline Distilled water & $3.9168(0.3049)$ & $1.6158(1.5402,1.6913)$ & $42.720(64)$ & $<0.001$ \\
Air-water syringe & $3.8109(0.2203)$ & $1.5099(1.4553,1.5645)$ & $55.247(64)$ & $<0.001$ \\
Low speed hand piece & $3.9186(0.2779)$ & $1.6176(1.5487,1.6865)$ & $46.926(64)$ & $<0.001$ \\
High speed hand piece & $3.9220(0.3030)$ & $1.6210(1.5459,1.6961)$ & $43.137(64)$ & $<0.001$ \\
\hline
\end{tabular}


Table 2. Comparison of heterotrophic plate count between output water from the air-water syringe, low and high speed hand pieces to that of distilled water source. Comparison was made using paired $t$ test and the $P$ values are as indicated in the table.

\begin{tabular}{ccccc}
\hline Water sources & Heterotrophic plate count (SD) & $\begin{array}{c}\text { Mean diff. } \\
(\mathbf{9 5 \%} \text { Cl) }\end{array}$ & t-statistic (df) & $\boldsymbol{P}$ value \\
\hline Distilled water & $3.9168(0.3049)$ & - & - & - \\
Air-water syringe & $3.8109(0.2203)$ & $0.1059(0.0325,0.1793)$ & $2.881(64)$ & 0.005 \\
Low speed hand piece & $3.9186(0.2779)$ & -0.0185 & & \\
& & $(-0.0280,0.0243)$ & $-0.141(64)$ & 0.888 \\
High speed hand piece & $3.9220(0.3030)$ & -0.0052 & & \\
\hline
\end{tabular}

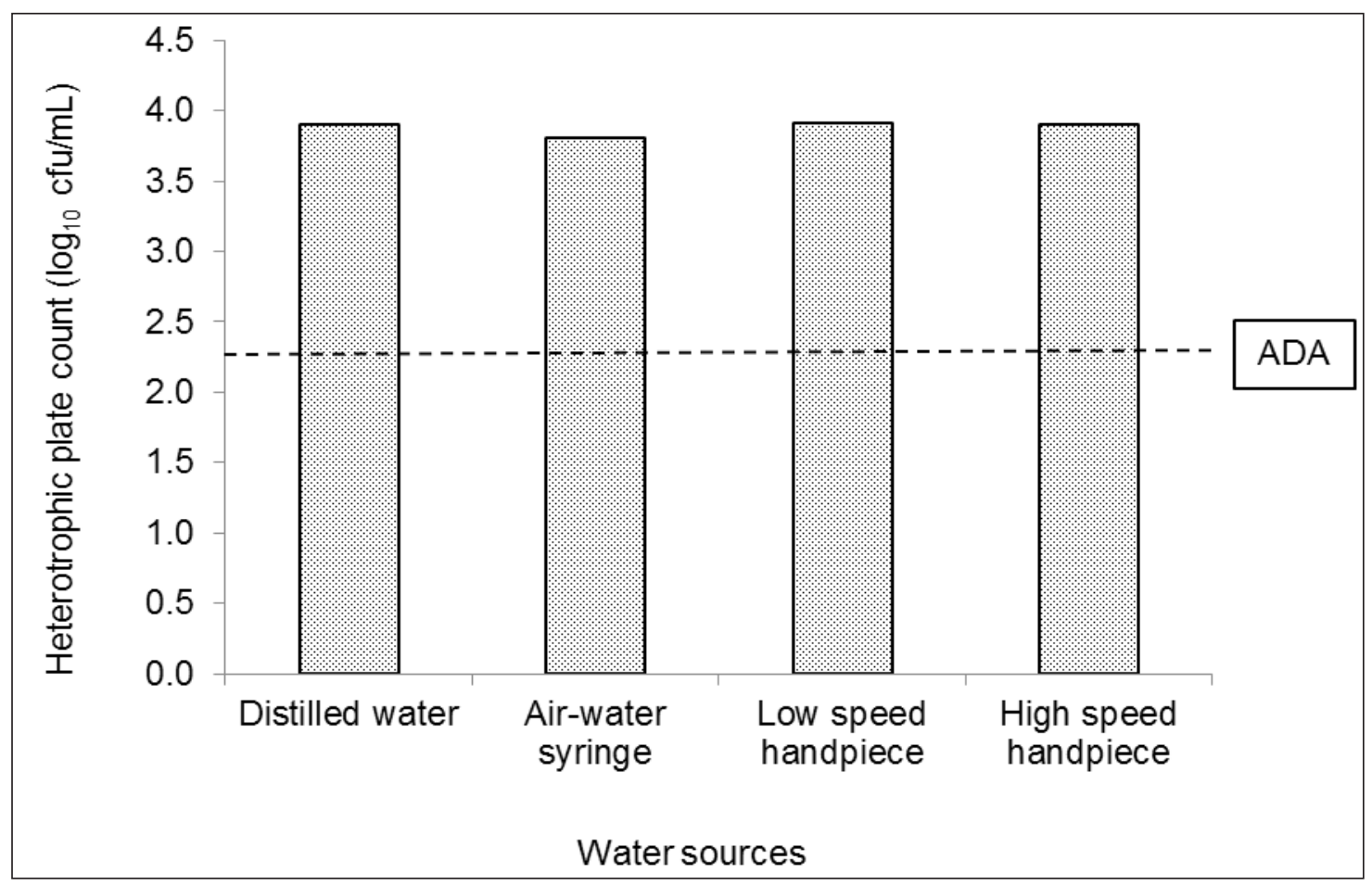

Figure 1. The mean of heterotrophic plate count from different water sources. The dotted line drawn across the bar chart represented the level of colony forming unit (cfu) below which is recommended by the American Dental Association (ADA) as acceptable for human consumption ( $\leq 200 \mathrm{cfu} / \mathrm{mL})$.

procedures is often of very small portion, this may not be an issue for serious concern.

Both the input and output water of the DCUs under study were also found highly loaded with microbes at levels exceeding that recommended by the ADA (Figure 1). Similar cases of high microbial loading in DCUs have also been reported in other developing countries like Brazil and Turkey $(15,16)$. It has also been reported that up to $51 \%$ of 237 DCUs studied across seven European countries showed microbial contamination exceeding the ADA recommendation (17). Although the influence of climate and water temperature in these reports was never mentioned, the very high bacterial population recorded in this study can be used to suggest that the warm environment in the clinic may have some contribution to the highly populated water. The accumulated excretions and metabolic end-products of microbial population have been suggested as a factor contributing to the acidity of 

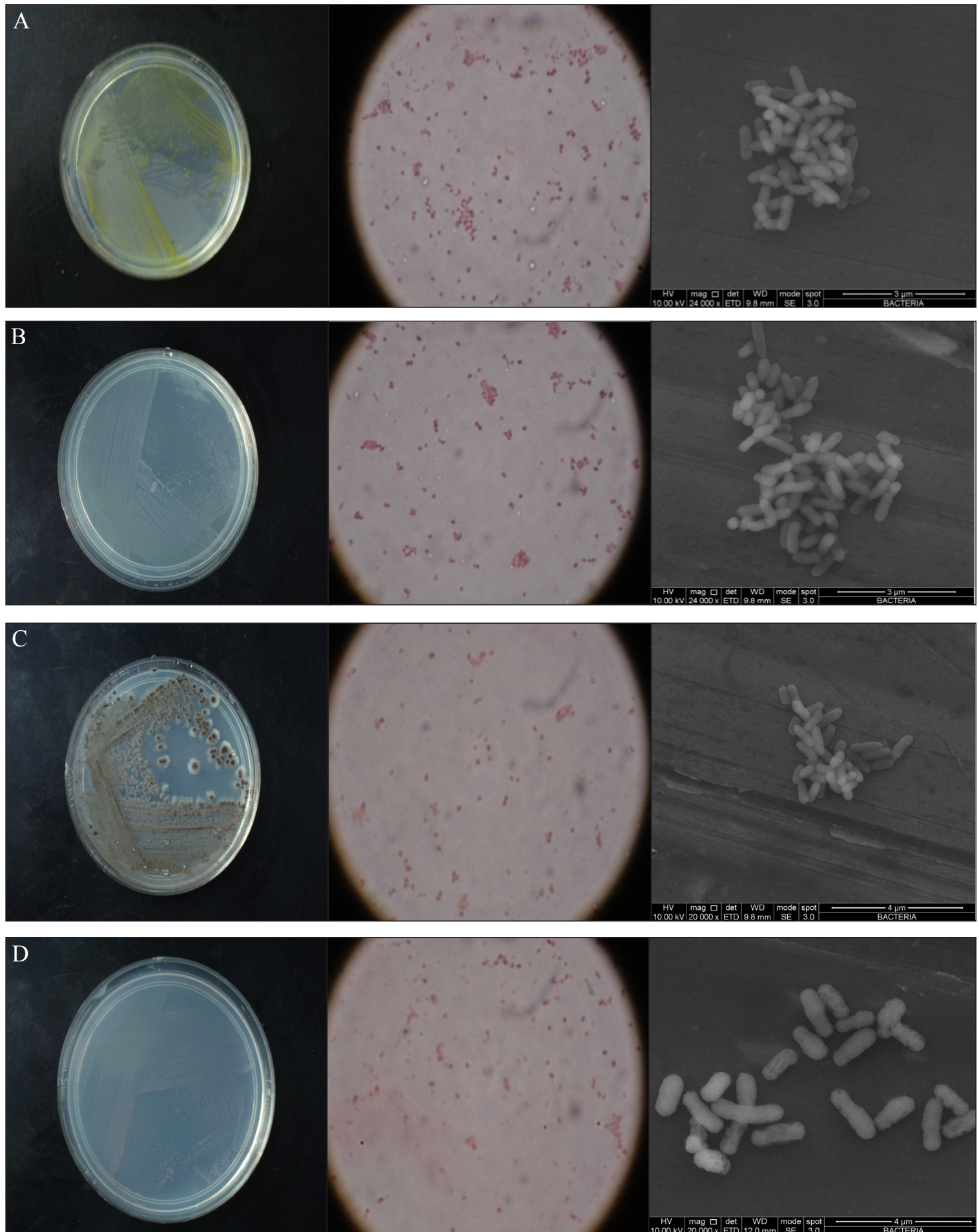

Figure 2. Microbial contaminants of DUWS water. Figures showing the colony, negative Gram-stained cells and morphological characteristics of the isolates identified via PCR technique as; (A) Sphingomonas rhizogenes, (B) Sphingomonas dokdonensis, (C) Sphingomonas mucosissima and (D) Methylobacterium radiotolerance

the DCU water. In general, microbial contamination of DUWS is a worldwide issue and in developing countries where the healthcare system is less extensive than in developed countries, is a cause for concern.

Four common bacteria were found to contaminate the DCU water and were identified as Sphingomonas dokdonensis, Sphingomonas rhizogenes, Sphingomonas mucosissima and Methylobacterium radiotolerans (Figure 2, Table 3). Sphingomonas is a group of chemoheterotrophic Gram-negative, strictly aerobic rod-shaped bacteria that are widely distributed in nature including clinical specimens. These microbes possess ubiquinone-10 as 
Table 3. Identity of common bacteria isolated from water samples as determined by comparing their $16 \mathrm{~S}$ rDNA gene sequences with that of GenBank database. The abundance percentages of these bacteria in the water samples are also presented.

\begin{tabular}{cc}
\hline $\begin{array}{c}\text { Bacterial species } \\
\text { (GenBank accession no.) }\end{array}$ & $\begin{array}{c}\text { Abundance } \\
\text { percentage (\%) }\end{array}$ \\
\hline $\begin{array}{c}\text { Sphingomonas rhizogenes } \\
\text { (AY962684.2) }\end{array}$ & 17.90 \\
$\begin{array}{c}\text { Sphingomonas dokdonensis } \\
\text { (DQ178975.1) }\end{array}$ & 79.50 \\
$\begin{array}{c}\text { Sphingomonas mucosissima } \\
\text { (AM229669) }\end{array}$ & 1.10 \\
$\begin{array}{c}\text { Methylobacterium radiotolerans } \\
\text { (GU294334.1) }\end{array}$ & 1.50 \\
\hline
\end{tabular}

the major respiratory quinine and unlike other bacterium, glycosphingolipids instead of lipopolysaccharide are contained in the cell envelopes (18). In general, most sphingomonads are not clinically important except for Sphingomonas paucimobilis which have been associated with a range of nosocomial infections (19). Methylobacterium is the other bacterium that contributed to the high microbial load of the water samples. Like the sphingomonads, Methylobacterium is also a rod-shaped Gram-negative and strictly aerobic. This bacterium can utilize one-carbon compound and the colonies appeared pinkish as they are pigmented with carotenoids. The presence of Methylobacterium sp. in DUWS has also been reported in other studies $(20,21)$. Despite the high microbial load of water from the DCUs, pathogenic bacteria including faecal coliforms, E. coli, faecal streptococci and P. aeruginosa were absent. On this account, the possibility of the DCU water to cause infection among patients receiving treatment in the clinic would be very unlikely and thus, can be considered safe for use.

\section{CONCLUSION}

It is concluded that water delivered via the DUWS in the clinic under study is safe for use in dental treatment procedures. Despite the high record of microbial load that failed to meet recommendation by the ADA, the water received by patients is free of pathogens. Sphingomonas dokdonensis that was found to be the most dominant contaminant is of no clinical importance. Further study is however required to discover new methods and approaches to ensure better quality of water is delivered in DUWS so as to minimise the risk of cross-infection among patients and dental personnel.

\section{ACKNOWLEDGEMENT}

We would like to acknowledge the contribution of clinical support staff at the faculty's Polyclinic. This study was financially supported by the University of Malaya Postgraduate Research Grant (PS081/2009C). The research outcome was presented at the International Conference on Prevention and Infection Control (CPIC 2013) in Geneva.

\section{REFERENCES}

1. Göksay D, Çotuk A, Zeybek Z. Microbial contamination of dental unit waterlines in Istanbul, Turkey Environ Monitor Assess 2008; 147: 265269.

2. Walker JT, Bradshaw DJ, Bennett AM, Fulford MR, Martin MV, Marsh PD. Microbial biofilm formation and contamination of dental unit water systems in general dental practice. Appl Environ Microbiol 2000; 66 (8): 3363-3367.

3. Szymańska J. Exposure to bacterial endotoxin during conservative dental treatment. Ann Agric Environ Med 2005; 12: 137-139.

4. Anonymous. ADA statement on dental unit waterlines. J Am Dent Assoc 1996; 127: 185-186.

5. Berlutti F, Testarelli L, Vaia F, De Luca M, Dolci G. Efficacy of anti-retraction devices in preventing bacterial contamination of dental unit water lines. $\mathrm{J}$ Dent 2003; 31 (2): 105-110.

6. Cobb CM, Martel CR, McKnight SA 3rd, PasleyMowry C, Ferguson BL, Williams K. How does time-dependent dental unit waterline flushing effect planktonic bacteria levels? J Dent Edu 2002; 66 (4): 549-555.

7. Walker JT, Bradshaw DJ, Fulford MR, Marsh PD. Microbiological evaluation of a range of disinfectant products to control mixed-species biofilm contamination in a laboratory model of a dental unit water system. Appl Environ Microbiol 2003; 69 (6): 3327-3332. 
8. Schel AJ, Marsh PD, Bradshaw DJ, Finney M, Fulford MR, Frandsen E, et al. Comparison of the efficacies of disinfectants to control microbial contamination in dental unit water systems in general dental practices across the European Union. Appl Environ Microbiol 2006; 72 (2): 1380-1387.

9. Montebugnoli L, Chersoni S, Prati C, Dolci G. A between-patient disinfection method to control water line contamination and biofilm inside dental units. J Hosp Infect 2004; 56 (4): 297-304.

10. Yabune T, Imazato S, Ebisu S. Assessment of inhibitory effects of fluoride-coated tubes on biofilm formation by using the in vitro dental unit waterline biofilm model. Appl Environ Microbiol 2008; 74 (19): 5958-5964.

11. Hunt ME, Rice EW. Microbiological examination. In: Eaton AD, Clresceri LS, Rice EW, Greenberg AE, Franson MAH. (ed). Standards Methods for the examination of water and wastewater: Centennial Edition (Standards Methods for the examination of water and wastewater) part 9000, p.9.1-9.169. Washingston, DC: American Public Health Association (APHA), American Water Works Association (AWWA) and Water Environment Federation (WEF) (publ.), 2005.

12. Kohn WG, Collins AS, Cleveland JL, Harte JA, Eklund KJ, Malvitz DM. Guidelines for infection control in dental health-care settings-2003. MMWR Recomm. Rep. 2003; 52(RR-17): 1-61.

13. Ricci ML, Fontana S, Pinci F, et al. Pneumonia associated with a dental unit waterline. Lancet 2012; 379(9816):684.

14. World Health Organization. Guidelines for drinking water quality. 2006. First to third editions, Vol. 1: Recommendations: addendum.-3rd ed. p. 221-466;
15. Souza-Gugelmin MCM, Lima CDT, Lima SNM, Mian H, Ito IY. Microbial contamination in dental unit waterlines. Braz. Dent. J. 2003; 14 (1): 55-57.

16. Türetgen I, Göksay D, Cotuk A. Comparison of the microbial load of incoming and distal outlet waters from dental unit water systems in Istanbul. Environ. Monitor. Assess. 2009; 158: 9-14.

17. Walker JT, Bradshaw DJ, Finney M, Fulford MR, Frandsen E, øStergaard E, Ten Cate JM. et al. Microbiological evaluation of dental unit water systems in general dental practice in Europe. Eur. J. Oral Sci. 2004; 112 (5): 412-418.

18. Takeuchi M, Hamana K, Hiraishi A. Proposal of the genus Sphingomonas sensu stricto and three new genera, Sphingobium, Novosphingobium and Sphingopyxis, on the basis of phylogenetic and chemotaxonomic analyses. Int. J. Sys. Evol. Microbiol. 2001; 51 (4): 1405-1417.

19. O’Donnell MJ, Shore AC, Coleman DC. A novel automated waterline cleaning system that facilitates effective and consistent control of microbial biofilm contamination of dental chair unit waterlines: a oneyear study. J. Dent. 2006; 34 (9): 648-661.

20. Barbeau J, Tanguay R, Faucher E, Avezard C, Trudel L, Côté L, Prévost AP. Multiparametric analysis of waterline contamination in dental units. Appl. Environ Microbiol. 1996; 62 (4): 3954-3959.

21. Wirthlin MR, Marshall Jr, GW, Rowland RW. Formation and decontamination of biofilms in dental unit waterlines. J. Periodontol. 2003; 74 (11): 15951609. 